\title{
Proportion of Pneumoconiosis In Limestone Mining Workers In Citatah Village, West Bandung District
}

\author{
Widhy Yudistira Nalapraya1, Agus Dwi Susanto ${ }^{2}$, Mukhtar Ikhsan², \\ Muchtarrudin Mansyur ${ }^{3}$, Caecilia Marliana4
}

\author{
${ }^{1}$ Faculty of Medicine, Bandung Islamic University \\ 2Department of Pulmonology and Respiration Medicine, Faculty of Medicine, Universitas Indonesia/ \\ Persahabatan Hospital, Jakarta \\ ${ }^{3}$ Department of Community Medicine, Faculty of Medicine, Universitas Indonesia, Jakarta \\ ${ }^{4}$ Faculty of Medicine, Trisakti University, Jakarta
}

\section{ABSTRACT}

Background: Silica, asbestos, and coal dusts correlate with pneumoconiosis in mineworkers. The International Labor Organization (ILO) reported that 30-50\% of workers in developing countries were diagnosed with pneumoconiosis. This study aimed to identify pneumoconiosis among limestone workers in Indonesia.

Method: This cross-sectional study involved 73 limestone mineworkers from two limestone mining sites in Citatah Village, West Bandung Regency, Indonesia, as the subjects. Two out of three AIR-Pneumo-certified blinded readers decided the conclusive chest X-ray (CXR) report of pneumoconiosis for each subject according to the ILO guidelines.

Results: Pneumoconiosis was found in $11 / 73$ (15.1\%) subjects. The median age of pneumoconiosis group was older compared to the non-pneumoconiosis group (51 [33-63] vs. 37.5 [18-85] years old, $P=0.013)$. All subjects in the pneumoconiosis group were of $>6$ years of working duration $(P=0.001)$. The dust concentration was higher at the mining site of the pneumoconiosis group compared to the mining site of the non-pneumoconiosis group ( $61.41 \pm 103.98$ vs. $\left.14.92 \pm 55.17 \mathrm{mg} / \mathrm{m}^{3}, \mathrm{P}=0.030\right)$. This study showed that working duration and mining site dust concentration were risk factors for pneumoconiosis; however, with no significance ( $O R=14.6, P=0.999$ and $O R=7,171, P=0.998$, respectively).

Conclusion: The proportion of pneumoconiosis in limestone mine workers in this study was $15.1 \%$. Working duration and mining site dust concentration were risk factors for pneumoconiosis; however, no significance was found from this study.

Keywords: pneumoconiosis risk factor, mining site dust, mining working duration, limestone mineworkers

*Correspondence: Widhy Yudistira Nalapraya - arijulian94@gmail.com

Submitted: January 13 th 2021, Accepted: February $9^{\text {th }}$ 2021, Published: February $28^{\text {th }} 2021$ 


\section{INTRODUCTION}

In the current era of industrialization, there has been an increase in industrial activity involving various other sectors such as mining. Mining workers are a vulnerable population that can contract occupational lung disease, one of which is pneumoconiosis. Data released by the World Health Organization (WHO) in 1999 showed that there were 1 million deaths among workers, 5\% of which were caused by pneumoconiosis. Data from the International Labor Organization (ILO) in 2013 shows that as many as $30-50 \%$ of workers in developing countries, one of them is Indonesia, experience pneumoconiosis. ${ }^{1}$

This fact is also supported by the results of research conducted at the University of Indonesia with a crosssectional study approach in 51 miners. The results of the study stated that there were $9.8 \%$ (5 people) experienced pneumoconiosis among mining workers. The level of dust in the mining work environment also has a much higher number than the safe limit of $10 \mathrm{mg} / \mathrm{m}^{3}$, which is $2.09347-22.4887$ $\mathrm{mg} / \mathrm{m}^{3}{ }^{2}$

Pneumoconiosis is a disorder that occurs due to the accumulation of dust in the lungs which causes a tissue reaction to the dust, the main reaction due to dust exposure is fibrosis. 2,3 Pneumoconiosis is caused by inhalation of dust which mostly comes from mining and agriculture. Globally, there are three types of mining dust that often cause pneumoconiosis, namely silica, asbestos and coal. ${ }^{3}$ Pneumoconiosis caused by chronic exposure to silica is known as silicosis. Apart from being found in mining areas, silica dust is also found in areas of sand blasting, stone cutting and quarrying. 3,4 Silicosis is known to manifest in pulmonary fibrosis which can progress even after the exposure is stopped. ${ }^{5}$

\section{METHOD}

This research is a cross sectional study. Limestone mining workers in Citatah Village, West Bandung Regency who meet the inclusion and exclusion criteria. The sample size uses the Slovin formula because the prevalence of pneumoconiosis in West Bandung Regency is not yet known, the total sample size is added by $10 \%$ of the calculation of the sample size as a reserve so that the sample size becomes 90 subjects.

The inclusion criteria were limestone miner and willing to participate in research with signed an informed consent. The exclusion criteria were had chronic lung disease 
(asthma, COPD, pulmonary tuberculosis) and a history of thoracic surgery before the worker worked in the mine.

Chest photo interpretation required for doctors who read thoracic photos based on NIOSH guidelines, namely that they already have an ILO certificate who is trained and experienced including interpreting chest photos and demonstrating competence in reading chest photos of pneumoconiosis for NIOSH B certificate qualifications and or nationally certified as a pulmonologist, radiologist, and occupational medicine. ${ }^{6}$ The reading of the ILO chest photo was carried out independently by two people, namely a pulmonary doctor and an occupational medical doctor who had an ILO certificate. Conclusions are drawn from the same two experiments.

The results of the ILO chest X-ray interpreted yes for a positive chest radiograph for pneumoconiosis and no for a chest X-ray for no pneumoconiosis. For the interpretation of shape and size, if two interpretations mention the regular small opacity form for any size between $p, q$ and $r$, it is concluded that the parenchymal abnormality of regular small opacity, the same applies to irregular small opacity and large opacity. For the density level, if two interpretations read the density between $1 / 0.1 / 1 / 1 / 2$ it is concluded that the density is 1 , if there are no two interpretations in a certain density level then it is written as descriptive.

\section{RESULT}

This study describes the main parameters namely therapeutic data and blood eosinophils in COPD patients, as well as several characteristics. These characteristics include gender, age, education, Brinkman index, duration of diagnosis, nutritional status (BMI), degree classification based on GOLD, and COPD group. There are 57 patients has been assessment. The characteristics of research subjects can be seen in Table 1.

This study is a cross-sectional test to determine the proportion of pneumoconiosis in limestone mining workers in Citatah Village, West Bandung Regency by using a screening questionnaire for chronic respiratory diseases, chest X-ray based on ILO guidelines and pulmonary function tests. The results of the chest photo were read by 2 readers from pulmonary doctors and occupational doctors. If there is a difference in the reading by the third reader, namely the radiology doctor, the conclusion drawn is the result of reading the two photos with 
the same conclusion. Citatah village has 5 companies that have limestone mines with a total population of 100 workers. The first thing to do in the research is to ask the company permission to conduct research from 5 companies, only 2 companies that give permission.

Table 1. General characteristics of limestone mining workers in Citatah Village, West Bandung Regency.

\begin{tabular}{lcccc}
\hline & \multicolumn{2}{c}{ Pneumoconiosis } & \multicolumn{2}{c}{ Not pneumoconiosis } \\
\cline { 2 - 5 } & $\mathbf{N}$ & $\mathbf{\%}$ & $\mathbf{N}$ & $\mathbf{\%}$ \\
\hline Limestone miner & 11 & 15.1 & 62 & 84.9 \\
\hline
\end{tabular}

Table 2. Characteristics of subjects based on pneumoconiosis

\begin{tabular}{|c|c|c|c|c|c|}
\hline \multirow{2}{*}{ Variable } & \multicolumn{2}{|c|}{ Pneumoconiosis } & \multicolumn{2}{|c|}{ Not pneumoconiosis } & \multirow{2}{*}{$\mathbf{P}$} \\
\hline & $\mathbf{N}$ & $\%$ & $\mathbf{N}$ & $\%$ & \\
\hline Age* & 51 & $33-63$ & 37.5 & $18-85$ & $0.013(b)$ \\
\hline \multicolumn{6}{|l|}{ Gender } \\
\hline Male & 11 & 100 & 54 & 87.1 & \multirow{2}{*}{$0.598(d)$} \\
\hline Women & 0 & 0 & 8 & 29.9 & \\
\hline \multicolumn{6}{|l|}{ Educational status } \\
\hline Junior High School & 5 & 45.5 & 42 & 67.8 & \multirow{3}{*}{$0.210(C)$} \\
\hline Middle High School & 4 & 36.4 & 11 & 17.7 & \\
\hline High school & 2 & 18.1 & 9 & 14.5 & \\
\hline \multicolumn{6}{|l|}{ Working time } \\
\hline$<8$ hours & 1 & 9,1 & 14 & 22.6 & \multirow{2}{*}{$0.441(d)$} \\
\hline$\geq 8$ hours & 10 & 90.9 & 48 & 77.4 & \\
\hline \multicolumn{6}{|l|}{ Smoking habit } \\
\hline Smoker & 10 & 90.9 & 41 & 66.1 & \multirow{3}{*}{$0.100(c)$} \\
\hline Former smoker & 0 & 0 & 1 & 1.6 & \\
\hline Not a smoker & 1 & 9,1 & 20 & 32.3 & \\
\hline \multicolumn{6}{|l|}{ Body Mass Index (BMI) } \\
\hline Less & 0 & 0 & 4 & 6.5 & \multirow{4}{*}{$0.734(c)$} \\
\hline Normal & 8 & 72.7 & 42 & 67.7 & \\
\hline More & 3 & 27.3 & 14 & 22.6 & \\
\hline Obesity & 0 & 0 & 2 & 3,2 & \\
\hline \multicolumn{6}{|l|}{ Length of working } \\
\hline$<6$ years & 0 & 0 & 37 & 59.7 & \multirow{3}{*}{$0.001(c)$} \\
\hline $6-10$ years & 8 & 72.7 & 17 & 27.4 & \\
\hline$>10$ years & 3 & 27.3 & 8 & 12.9 & \\
\hline \multicolumn{6}{|l|}{ Use of PPE } \\
\hline Yes & 2 & 18.2 & 15 & 24.2 & \multirow{2}{*}{$1,000(d)$} \\
\hline Not & 9 & 81.8 & 47 & 75.8 & \\
\hline
\end{tabular}


Table 2. Characteristics of subjects based on pneumoconiosis (cont.)

\begin{tabular}{lccccc}
\hline \multirow{2}{*}{ Variable } & \multicolumn{2}{c}{ Pneumoconiosis } & \multicolumn{2}{c}{ Not pneumoconiosis } & \multirow{2}{*}{ P } \\
\cline { 2 - 5 } & Median & Min-Max & Median & Min-Max & \\
\hline Interpretation of pulmonary function disorders & & & & & \\
$\quad$ Failed to maneuver & 1 & 9 & 5 & 8.1 & \\
Normal & 5 & 45.5 & 44 & 71 & \\
Restriction & 3 & 27.3 & 5 & 8.1 & $0.222(\mathrm{c})$ \\
Obstruction & 2 & 18.2 & 7 & 11.3 & \\
Mix & 0 & 0 & 1 & 1.5 & \\
Company dust level 1* $\left(\mathrm{mg} / \mathrm{m}^{3}\right)$ & 0.6966 & $0.6966-0.6966$ & 0.6966 & $0.6966-0.6966$ & $1.000(\mathrm{~b})$ \\
Company dust level 2* $\left(\mathrm{mg} / \mathrm{m}^{3}\right)$ & 223.3 & 0 & 40.78 & 88.1 & $0.002(\mathrm{a})$ \\
Dust level at 2 companies* & 61.41 & 103.98 & 14.92 & 55.27 & $0.030(\mathrm{a})$ \\
Work location & & & & & \\
Limestone mine & 8 & 72.7 & 58 & 93.5 & \\
Limestone mill & 3 & 27.3 & 4 & 6.5 & 0.065 (d)
\end{tabular}

Note: $(*)$ Mean value (standard deviation) for normal distribution; median (minimum-maximum) value for abnormal distribution; (\%) Percentage of total sample $(\mathrm{N}=73)$; (a) Unpaired T-test with the same variance; (b) Mann-whitney test; (c) Kendall's-tau; (d) Fisher's Test.

Table 3. Description of International Labor Organization chest X-ray abnormalities

\begin{tabular}{|c|c|c|c|}
\hline ILO classification & Reader 1 & Reader 2 & Reader 3 \\
\hline $\begin{array}{l}\text { Parenchymal abnormalities consistent with pneumoconiosis } \\
\text { shape }\end{array}$ & 6 & 0 & 6 \\
\hline $\mathrm{P}$ & 3 & 0 & 2 \\
\hline Q & 1 & - & 2 \\
\hline $\mathrm{R}$ & 1 & - & 1 \\
\hline S & 1 & - & 1 \\
\hline $\mathrm{T}$ & - & - & - \\
\hline U & - & - & - \\
\hline \multicolumn{4}{|l|}{ Profusion } \\
\hline $0 / 0$ & - & - & - \\
\hline $0 / 1$ & 5 & - & 2 \\
\hline $1 / 0$ & - & - & 1 \\
\hline $1 / 1$ & 1 & - & 1 \\
\hline $1 / 2$ & - & - & - \\
\hline $2 / 1$ & - & - & 1 \\
\hline $2 / 2$ & - & - & - \\
\hline $2 / 3$ & - & - & 1 \\
\hline Pleural abnormalities consistent with pneumoconiosis & 5 & 0 & 5 \\
\hline Costophrenic angle obliteration & 5 & 0 & 5 \\
\hline
\end{tabular}


The first company works only to take limestone with a total of 50 workers, the second company works taking limestone and then grinding limestone into lime flour has 30 workers. 80 workers were screened with a respiration questionnaire. Here, 5 people were excluded because 2 people had a history of chest injuries and 3 people had a history of pulmonary tuberculosis treatment while 2 more people refused to become the study subjects.

The total number of workers who met the study inclusion criteria was 73 people. Workers who met the inclusion criteria and were willing to take part in the study were subjected to a chest Xray of the ILO criteria and spirometry as many as 73 people, 73 thoracic photos are read by two readers independently, both readers do not know the results of the interpretation of one photo from another, there are 11 photos that have different interpretations from 2 readers then 11 photos are read by a third reader who is still carried out independently. according to NIOSH guidelines.

Out of a total of 73 workers, 11 people $(15.1 \%)$ had ILO chest radiographs according to pneumoconiosis. There were 5 people with parenchyma abnormalities with regular small opaque form, one small irregular opaque disorder measuring about $1.5 \mathrm{~mm}$. The density level of 2 people with a density of 0.1 people with a density of 1 , the other 3 people density is described in Table 3. Five subjects had pleural abnormalities that were compatible with pneumoconiosis and costoprenic obliteration.

Of the total subjects, the median age was 42 (range 18-85). Subject The majority of men were 65 people (89\%). The majority of education levels are SD graduates as many as 47 people (64.4\%). Time worked $\geq 8$ hours as many as 58 subjects (79.5) The majority of subjects were smokers as many as 51 people (69.9\%). The body mass index of the majority of the subjects was normal as many as 50 people $(68.5 \%)$. The majority of the subjects $<6$ years old were 37 people $(50.7 \%)$. The majority of subjects did not use PPE as many as 56 people (76.7\%).

Pulmonary physiology examination of the subjects median CVD $3300 \mathrm{ml}$ (1310-4570 ml), \%KV median 97.8\% (65.1-168\%), median CVP $3270 \mathrm{ml}(1200-4500 \mathrm{ml})$, \%FVC median 96.2\% ( 64-164\%), median $\mathrm{FEV}_{1} 2680 \mathrm{ml}(910-3840 \mathrm{ml}), \% \mathrm{FEV}_{1}$ median 95\% (39.3-173\%) and median $\% F_{1} / F V C \quad 83.2 \% \quad(42.5-96.9 \%)$ Pulmonary function disorders, the majority of obstruction disorders, were 
9 people $(12.3 \%)$.

\section{DISCUSSION}

According to the International Labor Organization pneumoconiosis is a non-neoplastic disorder that occurs due to the accumulation of dust in the lungs which results in finger reactions, especially fibrosis reactions. ${ }^{7,8}$ The oldest type of pneumoconiosis is known as silicosis, which is a diffuse interstitial fibronodular lung disease caused by inhalation of crystalline silica, one of which is often found in limestone mining workers. ${ }^{8}$

In this study, there were 11 out of 73 people $(15.1 \%)$ workers of limestone miners with ILO chest X-rays according to pneumoconiosis. The proportion of limestone mining worker pneumoconiosis in Citatah Village, West Bandung Regency is higher than in several other studies in Indonesia, research by Pandu et al. in 2005 in a steel knife factory in 2002 found $5 \%$ of radiological images suspected of pneumoconiosis, Bangun et al's research in 2017 on stone mining workers at PT. A in Bandung found $9.8 \%$ pneumoconiosis and research by Damayanti et al. in 2007 on cement factories also found $4.9 \%$ cases of pneumoconiosis from chest X-ray examination. $2,7,9$

Research data in the United Kindgom, there has been a decrease in the incidence of silicosis and CWP in the last 10 years. There were 30 new cases of silicosis in 2017 reported by the Industrial Injuries Disablement Benefit (IIDB), compared to 85 in 2008 with the discovery of new silicosis cases. Research in China, pneumoconiosis is classified into 13 categories, namely; silicosis, coal workers Pneumoconiosis (CWP), graphite pneumoconiosis, and others. In 2008 to 2013, there were 3,665 cases of pneumoconiosis (85.61\% of all occupational diseases) reported in Hubei province. ${ }^{10}$

Other studies in China stated that more than $70 \%$ of pneumoconiosis cases were silicosis cases in the cities of Wuxi, Yancheng, and Suzhou. This may be related to population size and industrial structure, and the type of economy in the ability to prevent and control occupational diseases. ${ }^{11}$

Centers for Disease Control and Prevention (CDC) in 2012 stated that there were $7 \%$ cases of pneumoconiosis from 2005-2009 based on radiographs from workers with 25 years of exposure. ${ }^{12}$ The incidence of pneumoconiosis in some developed countries has decreased. This is because there are disease prevention 
programs recommended by legal institutions, including ventilation systems, sprinklers and dust capture devices. In several industries, the use of masks as protection has been promoted. Periodic examinations, such as spirometry and radiographs on workers are carried out every 5 years. ${ }^{11,12}$

Physiological disorders of the lungs and respiratory tract in labour, including in limestone mining workers, can be influenced by internal (from within humans) and external (from outside humans). ${ }^{13}$

The analysis conducted in this study showed that there was a relationship between age and the incidence of pneumoconiosis in limestone miners in Citatah Village, West Bandung Regency in 2018 with $\mathrm{P}=0.013$. This is consistent with research conducted by Isara et al. (2016) on 113 mining workers consisting of 76 field workers as cases and 37 office workers as controls in Edo State, Nigeria with $\mathrm{P}=0.01$ workers who have respiratory symptoms in workers. mines exposed to dust compared to workers who were not exposed had an age of $42 \pm 12.7$ years versus $36.2 \pm 10.6 .{ }^{14}$

This is also supported by the research of Tolinggi et al. (2015) with a value of $\mathrm{P}=0.005$ which compared serum IL-8 levels and pulmonary function in 9 limestone mining industry workers in Wangun Village, Palang District, Tuban Regency as a case with 9 workers in the Semanding District office as a control. Mining workers carry out activities such as excavating, crushing, and cutting limestone without the use of PPE. ${ }^{15}$ The pathogenesis of pneumoconiosis is determined by two main factors, namely dust particles in the form of concentration and particle size $(<5 \mu \mathrm{m})$ and individual vulnerability in the form of body response, especially the airway to particles the dust. ${ }^{14,16}$

Age factor affects the vulnerability of the body, physical condition and lung function capacity. Pulmonary function capacity will continue to increase to a maximum point at the age of 19 to 21 years and then decrease with age. At the age of 30 years, the average lung capacity is $3000-3500 \mathrm{ml}$ while at the age of 50 years it decreases to less than $3000 \mathrm{ml}$. Other than that, older age had a higher sensitivity to COPD and the cumulative total dust exposure. This condition will be exacerbated by a dusty environment and other factors such as smoking habits and diseases related to the respiratory tract. ${ }^{17,18}$

Research conducted by Apsari et al. (2018) showed insignificant results on the relationship between age and occupational lung disease in 31 sand 
and stone mining workers in Rowosari Village, Semarang City in 2017 $(P=1.000)$. This difference may be due to this study using a numerical scale for age, whereas Apsari et al. (2018) made age into a nominal scale by dividing the age group into two, namely the age group $>30$ years and $\leq 30$ years. At the age of 30 years, lung capacity has decreased, but the respiratory muscle function will significantly decrease about $20 \%$ at the age of 40 years. ${ }^{19}$

Based on the results relationship between length of work and the incidence of pneumoconiosis in workers in a limestone mine in Citatah Village, West Bandung Regency in 2018 $(P=0.001)$. This is in line with the theory and research conducted by Budiono (2007) and Simanjuntak et al. (2015) who stated that the length of work had a significant relationship with the incidence of pneumoconiosis, related to the cumulative dose of dust particles in the lungs. The composition of limestone consists of $95 \% \mathrm{CaCO}_{3}$, $11 \% \mathrm{MgCO}_{3}$, and $1-20 \%$ crystalline silica which, if exposed for a long period of time and with a weight of $2-5 \mathrm{mg} / \mathrm{m}^{3}$ caused an inflammatory reaction. ${ }^{17,20} \mathrm{~A}$ multivariate analysis of length of work with pneumoconiosis was performed $\mathrm{OR}=14.639$ and $\mathrm{P}=0.989$. It is concluded that the longer working in this study is divided into $>10$ years has a 14.639 times risk of developing pneumoconiosis compared to mining workers who work $<6$ years although it is not statistically significant.

In contrast to this study which divided the sample into three categories, namely, length of work $<6$ years, 6-10 years and> 10 years, Budiono (2007) and Simanjuntak et al (2015) only divided the sample into two, namely, length of work $<10$ years and $\geq 10$ years. Splitting the division into 3 (three) groups was carried out to reduce bias due to the uneven distribution with the number of samples with a length of service $>10$ years of only $12.32 \% .{ }^{17,20}$ This can be caused by individual susceptibility factors and a history of dust exposure in previous places not studied and is a limitation of this study. ${ }^{21}$

The results of the variable analysis of dust levels on pneumoconiosis in the study in company 2 with $\mathrm{P}=0.002$, versus $\mathrm{P}=1.000$ in company 1 . Research by Simajuntak et al divides dust levels into high $\left(>3 \mathrm{mg} / \mathrm{m}^{3}\right)$ and low $\left(\leq 3 \mathrm{mg} / \mathrm{m}^{3}\right)$. Of the total subjects with high dust levels of 28 people, 18 subjects (64.3\%) had chest X-ray images of pneumoconiosis, while 10 subjects who did not have chest X-ray images of pneumoconiosis (35.7\%). Meanwhile, from a total of 10 subjects with low dust levels, there are 2 
subjects (20\%) had chest X-ray images of pneumoconiosis while 8 subjects $(80 \%)$ had no features of pneumoconiosis. The results of the analysis of the relationship between dust levels and the incidence of pneumoconiosis obtained a significance value of $P=0.027$.

Besides, Tse LA, et al (2015) conducted a retrospective cohort study of 3,492 workers exposed to silica from iron ore, with a monitoring time of 33 years. This study developed a risk scoring system using a linear combination of predictor values by LASSO. Six predictors were selected into the final prediction model; age at entry, mean concentration of inhaled silica, years of exposure, smoking, illiteracy, and number of jobs. In this study, the mean predictors of inhaled silica dust were divided into $<0.05 \mathrm{mg}$ / m3 (coefficient value 0 and HR 1.00), $0.05-0.10 \mathrm{mg} / \mathrm{m}^{3}$ (coefficient value 2.14 and HR. 8.52 (95\% CI 3.96-18.33)), 0.10-0.15 mg / m3 (coefficient value 3.41 and $H R=30.28$ (95\% $\mathrm{CI}=14.08$ 65.13 ), and $\geq 0.15 \mathrm{mg} / \mathrm{m}^{3}$ (coefficient value 4.23 and $H R=68.64 \quad(95 \%$ $\mathrm{CI}=31.83-147.98)$ with $\mathrm{P}<0.001) .{ }^{22}$

Buchanan D, et al. (2003) who conducted monitoring on 547 workers. For workers who aged $50-74$ years, the logistic regression model is calculated by dividing the two time periods. In the period before 1964 , the OR for the $2 / 1+$ risk was 0.995 (95\% CI=0.977-1.014) and the post 1964 OR for 2/1+ was 1.811 (1.536-2.136). The calculation of the risk of silicosis must take into account the intensity of quartz exposure, particularly at concentrations of 1 or $2 \mathrm{mg} / \mathrm{m} 3$, even though the exposure time period is brief. ${ }^{23}$

In this study, the cumulative quartz exposure group was divided into $<2 \mathrm{mg} / \mathrm{m}^{3}$ and $\geq 2 \mathrm{mg} / \mathrm{m}^{3}$. Even though these two exposures are in the same unit, the coefficient at the higher dust concentration is tripled. The calculation model used in this study predicts a silicosis risk of $2.5 \%$ over 15 years of $0.1 \mathrm{mg} / \mathrm{m}^{3}$ dust exposure. which increased to $10.6 \%$ with the addition of only four months of exposure to a concentration of $2 \mathrm{mg} / \mathrm{m}^{3}$, and to $72 \%$ annually at higher exposures. Estimated exposure of $1 \mathrm{~g} \cdot \mathrm{h} / \mathrm{m}^{3}$ at concentrations $>2 \mathrm{mg} / \mathrm{m}^{3}$ corresponds to the predicted risk of a radiographic abnormality of about $3 \mathrm{~g} . \mathrm{h} / \mathrm{m}^{3}$. This study did not detect the effect of time of exposure. ${ }^{23}$

Based on the analysis of the results of the research conducted, it was found that $P=0.598$ showed that gender was not related to the incidence of pneumoconiosis in limestone mining workers in Citatah Village, West Bandung Regency in 2018. This is 
supported by research conducted by Isara et al. (2016) with results $P=0.59$, Blackley et al. (2014) with $P=0.44$ and Yen et al. (2015) with $P=0.99 .14,24,25$ In contrast to this study, research by Brass et al. (2010) proved that there was a significant relationship between female and male sex in miceC57BL/6 $(P<0.005)$ by attributing the expression of Esterogen Receptor alpha (ER-a) to the incidence of silicosis in mice induced intratracheal silica crystalline 0.2 $\mathrm{g} / \mathrm{kg}^{26}$

Esterogens can induce TNF-a production in macrophages and increase macrophage-specific chemokines in fibrosis and lung tissue inflammation. ${ }^{27}$ Macrophages are a cellular immune system that clears small particles by means of phagocytosis, TNF-a is an indicator of the prognosis of pneumoconiosis. Furthermore, in response to TNF- $a$ and IL-1, IL-8 will act as chemokines released by various cell types including fibroblasts, then activate and call neutrophils which in turn induce the inflammatory process. ${ }^{26}$

The results of the analysis in this study showed that nutritional status related to the incidence of pneumoconiosis in limestone mining workers in Citatah Village, West Bandung Regency in 2018 ( $P=0.734)$. This is supported by research conducted by Zheng et al. (2017) with $\mathrm{P}=0.134 .^{28}$

The results of the analysis in this study indicate that there is no significant relationship between educational status and the incidence of pneumoconiosis in limestone mining workers in Citatah Village, West Bandung Regency in 2018 ( $P=0.210)$, according to the research conducted by Isara et al. (2016) on 113 mining workers consisting of 76 field workers as cases and 37 office workers as controls in Edo State, Nigeria with a result of $\mathrm{P}=0.25 .{ }^{14}$ However, research conducted by Ayaaba et al. (2017) on 1001 male workers in Obuasi and Tarkwa from December 2015 to April 2016 showed significant results $(P<0.001) .29$

The results of the analysis in this study indicate that there is no relationship between working time and the incidence of pneumoconiosis in limestone mining workers in Citatah Village, West Bandung Regency in 2018 $(P=0.441)$ because in this study the majority of workers worked more than 8 hours, namely 58 workers (79.5\%) so it is difficult to describe the relationship between working time and pneumoconiosis. This result is supported by research conducted by Budiono et al. (2007). ${ }^{17}$ The results of this study are inconsistent with the 
theory of increased risk of exposure and incidence of occupational diseases during longer working hours. ${ }^{30}$

The results of the analysis in this study showed that there was relationship between smoking habits and the incidence of pneumoconiosis in limestone mining workers in Citatah Village, West Bandung Regency in 2018 $(P=0.100)$. This is supported by research conducted by Budiono $(2007)^{17}$ and Isara et al. (2016). ${ }^{17}$ Which is also in line with the research by Tolinggi et al. (2015) on workers in the limestone mining industry in Wangun Village also supports the results of this study with a value of $\mathrm{P}=0.885$ despite the different scale variables in the research of Tolinggi et al. (2015) used a numerical scale for the number of cigarettes per day, while this study used an ordinal scale which divided the sample into three groups, namely smokers, former smokers and non-smokers. ${ }^{15}$ Research conducted by Apsari et al. (2018) also did not show a significant relationship between smoking habits and the incidence of lung disease due to work on 31 sand and stone mining workers $(P=0.139) .{ }^{19}$ This indicates that smoking habits are not a major factor in the incidence of pneumoconiosis.

Chemical substances in cigarettes such as nicotine, tar, $\mathrm{CO}$, and nitrosamine can damage the cilia hairs in the airways which function as a filter for air that enters breathing and activate alveolar macrophages and inflammatory cells which in turn induce chronic inflammation of the airway, lung parenchyma, and pulmonary vessels. $28,30,31$

Based on the analysis of the relationship between the use of PPE and the incidence of pneumoconiosis, the $p$ value is 1,000 . This result is supported by research conducted by Pinugroho et al. (2015) with a value of $P=0.250$ and Apsari et al. (2018) with a value of $P=1,00 .^{19}$

The use of standard masks recommended by NIOSH for mining workers, there are two basic principles, namely a respirator preventing particles from entering the airway, the second is called air-purifying respirators. for dust particles, the use of respirators is the simplest type, and the simplest recommended is the use of N95 masks. ${ }^{32}$ Research conducted by Khumaidah (2009) on 44 furniture workers showed different results in the form of a significant relationship between the use of PPE and pulmonary function disorders. Workers who do not use PPE in the form of masks have a risk of pulmonary disorders of 6 times compared to workers who use PPE masks. ${ }^{33}$ 
Analysis of the relationship between work location and pneumoconiosis in limestone mining workers in Citatah Village, West Bandung Regency $\mathrm{P}=0.065$ because the majority of research subjects work in the limestone mine, namely 66 people compared to 7 people in the limestone mill, but after multivariate analysis Work location is the third risk factor for pneumoconiosis because the dust mill is the location with the highest dust content, which is $223.3 \mathrm{mg} / \mathrm{m}^{3}$ because the limestone mill is a closed room so that dust can not be blown away by the wind. This study is in accordance with the research of Simanjuntak et al. (2015) conducted research on cement collecting workers in the cement packing unit of PT. The Tonasa Line of Bitung City at that location using dust measurements with a personal dust sampler obtained 28 subjects $(73.6 \%)$ of 38 subjects exposed to high dust levels $>3$ $\mathrm{mg} / \mathrm{m}^{3} .^{20}$

The results of the analysis of lung function variables on the incidence of pneumoconiosis in this study did not show relationship between lung function and pneumoconiosis with a value of $\mathrm{P}=0.235$ in $\mathrm{VC}, \mathrm{P}=0.705$ in $\% V C, P=0.238$ for $F V C, P=0.683$ at $\% F V C, P=0.170$ for $F E V_{1}, P=0.649$ for $\% \mathrm{FEV}_{1}$ and $\mathrm{P}=0.141$ for $\% \mathrm{FEV}_{1} / \mathrm{FVC}$.
Compared to the research of Damayanti et al. On cement workers PT. X, it was found that 56 workers (30.8\%) had pulmonary function abnormalities in the form of restriction disorders 35 people (19.2\%) 15 people $(8.2 \%)$ obstruction disorders (8.2\%) and mixed disorders 6 People (3.3\%). ${ }^{9}$

Research conducted by Zhu et al (2017) on 75 workers with silicosis from the same molybdenum mine in a small Chinese town proved that silicosis was radiographically significant in all parameters between stages I, II, and III. Zhu et al. (2017) also found that increasing the extent of silicotic lesions associated with regions had a more significant reduction in pulmonary function with progressive massive fibrosis in $\mathrm{FEV}_{1}, \mathrm{FEF}_{75}, \mathrm{FEF}_{50}$, and $\mathrm{FEF}_{25}$ $(\mathrm{P}<0.05) .^{34}$

Research conducted by Tonori et al. (2005) also showed similar results, namely $\mathrm{KV}$ and $\mathrm{FEV}_{1}$ in workers with lower silica exposure compared to workers who were not exposed to silica and asbestos $(P<0.001) .{ }^{35}$ The results of Ergun et al. (2017) also showed that There was a significant association between pulmonary function disorders and all radiological abnormalities, namely chest X-ray and High Resolution Computed Tomography (HRCT) for dental technicians with nodular perfusion (NP) values for chest X-ray 
are FVC $(r=-0.448 ; \mathrm{P}<0.001)$ and $\mathrm{FEV}_{1}$ $(P<0.001 ; r=-0.460)$. NP values for total score are FVC $(r=-0.499$; $\mathrm{P}<0.001): \mathrm{FEV}_{1}(\mathrm{r}=-0.446 ; \mathrm{P}<0.001)$. And NP values for opacity score parenchyma are FVC ( $r=-0.417$; $P<0.001), \operatorname{FEV}_{1}(r=-0.400 ; P<0.001) .{ }^{36}$

Research conducted by $\mathrm{Nij}$ et al (2013) conducted on 64 mining workers in the UK also showed similar results to this study, namely that there was no significant relationship between pulmonary function and radiological features in patients with pneumoconiosis $\quad(P=0.09)$. This differences can be caused by the small opacity class and density of silicosis there is no significant difference in pulmonary function parameters. ${ }^{34,37}$

\section{CONCLUSION}

The proportion of pneumoconiosis in limestone mining workers in Citatah Village, West Bandung Regency is $15.1 \%$. Characteristics of limestone mining workers in Citatah, West Bandung Regency, median age of 42 years, the majority of workers are male, the majority of workers are in primary school, the majority of workers work $\geq 8$ hours, the majority of workers are smokers, the majority of workers' nutritional status is normal, the majority of workers have worked $<6$ years, the majority of workers do not use masks, the majority of workers' pulmonary functions are normal, the highest level of company dust is 223.30 $\mathrm{mg} / \mathrm{m}^{3}$ and the majority of workers work in a limestone mine. The factors that influence the incidence of pneumoconiosis are length of work and dust level.

\section{REFERENCES}

1. Kementrian Kesehatan RI. Pekerja Industri Pertambangan Rentan Terkena Pneumoconiosis - Sehat Negeriku. Published 2017. Accessed December 17, 2017. https://sehatnegeriku.kemkes.go. id/baca/rilismedia/20151109/3713697/pekerj a-industri-pertambangan-rentanterkena-pneumoconiosis/

2. Bangun U, Widjaya M. Analisis epidemiologis pneumokoniosis berdasarkan X-ray paru klasifikasi standar International Labour Organization (ILO) pada pekerja tambang batu PT. A di Bandung Jawa Barat. Published 2017. Accessed December 13, 2017. http://lib.ui.ac.id/bo/uibo/detail.js p?id=77360\&lokasi=lokal

3. Stansbury RC, Petsonk EL, Parker JE. Coal Workers' Lung Diseases and Silicosis. In: Fishman's Pulmonary Diseases and Disorders. McGraw-Hill Medical; 
2008:933-980.

4. Loscalzo J, Harrison $T$. Environmental Lung Diseases. In: Harrison's Manual of Medicine. McGraw-Hill Medical; 2013:93104.

5. Bhattacharya S, Dey A, Pal A, Kar $S$, Saha S. Silicosis in the form of progressive massive fibrosis: A diagnostic challenge. Indian $J$ Occup Environ Med. 2016;20(2):114-117.

6. The National Institute for Occupational Safety and Health. Application of Digital Radiography for the Detection and Classification of Pneumoconiosis.; 2011.

7. Rosner D. The Long Struggle to Protect Workers' Lungs Against Silicosis. Milbank Q. 2014;92(2):191-194.

8. Santos C, Norte A, Fradinho F, et al. Silicosis - brief review and experience of a pulmonology ward. Rev Port Pneumol (English Ed. 2010;16(1):99-115.

9. Damayanti T, Yunus $F$, Ikhsan M, Sutjahyo K. Hubungan Penggunaan Masker dengan Gambaran Klinis, Faal Paru dan Foto Toraks Pekerja Terpajan Debu Semen - PDF Free Download. Maj Kedokt Indon. 2007;57(9):289-299.

10. Chong S, Lee KS, Chung MJ, Han
J, Kwon OJ, Kim TS. Pneumoconiosis: Comparison of imaging and pathologic findings. Radiographics. 2006;26(1):59-77.

11. Han L, Yao W, Bian $Z$, et al. Characteristics and trends of pneumoconiosis in the Jiangsu Province, China, 2006-2017. Int J Environ Res Public Health. 2019;16(3).

12. Centers for Disease Control and Prevention. Coal workers' health surveillance program - data query system. Published 2012. Accessed July $\quad 31,2019$. http://webappa.cdc.gov/ords/cwh sp-database.html.

13. Petsonk EL, Rose C, Cohen R. Coal mine dust lung disease: New lessons from an old exposure. $\mathrm{Am}$ $J$ Respir Crit Care Med. 2013;187(11):1178-1185.

14. Isara AR, Adam VY, Aigbokhaode AQ, Alenoghena IO. Respiratory symptoms and ventilatory functions among quarry workers in Edo state, Nigeria. Pan Afr Med J. 2016;23.

15. Tolinggi S, Nakoe MR, Gobel A, et al. Effect Inhaling of Limestone Dust Exposure on Increased Level of IL-8 Serum and Pulmonary Function Decline to Workers of Limestone Mining Industry. Int Ref J Eng Sci. 2014;3(8):66-72. 
16. Pérez-Alonso A, Córdoba-Doña JA, Millares-Lorenzo JL, FigueroaMurillo E, García-Vadillo C, Romero-Morillo J. Outbreak of silicosis in Spanish quartz conglomerate workers. Int $J$ Occup Environ Health. 2014;20(1):26-32.

17. Budiono I. Faktor risiko gangguan fungsi paru pada pekerja pengecatan mobil (Studi pada bengkel pengecatan mobil di Kota Semarang). Published online 2007.

18. Peng $Y, L i ~ X$, Cai $S$, et al. Prevalence and characteristics of COPD among pneumoconiosis patients at an occupational disease prevention institute: $A$ cross-sectional study. BMC Pulm Med. 2018;18(1):22.

19. Apsari L, Budiyono, Setiani O. Hubungan paparan debu terhirup dengan gangguan fungsi paru pada pekerja pertambangan pasir dan batu perusahaan $X$ Rowosari Kota Semarang. J Kesehat Masy. 2018;6(4):2356-3346.

20. Simanjuntak ML, Pinontoan $O R$, Pangemanan JM. Relationship Between Level Of Dust, Work Period, Use Of Mask And Smoking With Pneumokoniosis Occurrence On Cement Collector Workers At Cement Packing Unit PT. Tonasa
Line Bitung.

JIKMU. 2015;5(5):520-532.

21. Cecala A, O'Brien A, Schall J, et al. Dust Control Handbook for Industrial Minerals Mining and Processing. Department of Health and Human Services; 2012.

22. Tse LA, Dai J, Chen $M$, et al. Prediction models and risk assessment for silicosis using a retrospective cohort study among workers exposed to silica in China. Sci Rep. 2015;5.

23. Buchanan D, Miller BG, Soutar CA. Quantitative relations between exposure to respirable quartz and risk of silicosis. Occup Environ Med. 2003;60(3):159-164.

24. Blackley DJ, Halldin CN, Wang ML, Laney AS. Small mine size is associated with lung function abnormality and pneumoconiosis among underground coal miners in Kentucky, Virginia and West Virginia. Occup Environ Med. 2014;71(10):690-694.

25. Yen $\mathrm{CM}$, Lin $\mathrm{CL}$, Lin $\mathrm{MC}$, Chen $\mathrm{HY}$, Lu NH, Kao CH. Pneumoconiosis increases the risk of congestive heart failure. Med (United States). 2016;95(25).

26. Brass DM, McGee SP, Dunkel MK, et al. Gender influences the response to experimental silicainduced lung fibrosis in mice. $A m \mathrm{~J}$ 
Physiol - Lung Cell Mol Physiol. 2010;299(5).

27. Sansores RH, Ramírez-Venegas A. COPD in women: Susceptibility or vulnerability. Eur Respir J. 2016;47(1):19-22.

28. Zheng $Y$, Liang $L$, Qin $T$, et al. Cross-section analysis of coal workers' pneumoconiosis and higher brachial-ankle pulse wave velocity within Kailuan study. BMC Public Health. 2017;17(1):1-8.

29. Ayaaba E, Li Y, Yuan J, Ni C. Occupational respiratory diseases of miners from two gold mines in Ghana. Int J Environ Res Public Health. 2017;14(3).

30. Yurdasal B, Bozkurt N, Bozkurt AI, Yilmaz Ö. The evaluation of the dust-related occupational respiratory disorders of dental laboratory technicians working in Denizli Province. Ann Thorac Med. 2015;10(4):249-255.

31. Qian QZ, Cao XK, Shen FH, Wang Q. Correlations of smoking with cumulative total dust exposure and cumulative abnormal rate of pulmonary function in coal-mine workers. Exp Ther Med. 2016;12(5):2942-2948.

32. The National Personal Protective Technology Laboratory (NPPTL). Approved Respirators, What are they? Centers for Disease Control and Prevention. Published 2019. Accessed September 8, 2019. https://www.cdc.gov/niosh/npptl/ topics/respirators/disp_part/resps ource1quest1.html

33. Khumaidah. Analisis faktor-faktor yang berhubungan dengan gangguan fungsi paru pada pekerja mebel PT. Kota Jati Furnindo Desa Suwawal Kecamatan Mlonggo Kabupaten Jepara. Published online 2009.

34. Zhu Q, Jiang Y. Correlation analysis between pulmonary function and chest radiograph in molybdenum mine works. Biomed Res. 28(9).

35. Tonori $Y$, Niitsuya $M$, Sato $T$, Sugiura $Y$, Miyake $H$, Aizawa $Y$. Relationship between chest X-ray findings and pulmonary function tests in dust workers. Ind Health. 2005;43(1):256-266.

36. Ergün $R$, Ergün $D$, Evcik $E$, Ergan B. Evaluation of dental technician's pneumoconiosis using chest X-ray and HRCT: correlation between radiological and functional findings. Turkish $\mathrm{J}$ Med Sci. 2017;47:252-259.

37. Tjoe-Nij E, De Meer G, Smit J, Heederik D. Lung function decrease in relation to pneumoconiosis and exposure to quartz-containing dust in 
construction workers. $A m \mathrm{~J}$ Ind

Med. 2003;43(6):574-583. 